This is an author's accepted manuscript for 'Media, Culture \& Society', copyright SAGE.

Black J (2016) ‘As British as fish and chips’: British Newspaper Representations of Mo Farah during the 2012 London Olympic Games. Media, Culture \& Society 38(7): 979-996.

To link to this article: http://mcs.sagepub.com/content/38/7/979.abstract

'As British as fish and chips': British Newspaper Representations of Mo Farah during the 2012 London Olympic Games

Dr. Jack Black, Academy of Sport and Physical Activity, Faculty of Health and Wellbeing, Sheffield Hallam University, Collegiate Hall, Collegiate Crescent, Sheffield, S10 2BP 


\title{
'As British as fish and chips’: British Newspaper Representations of Mo Farah during the 2012 London Olympic Games
}

\section{Jack Black, PhD}

Academy of Sport and Physical Activity, Sheffield Hallam University, Sheffield, UK

\begin{abstract}
This paper examines British newspaper representations of the 'Team GB' athlete Mohamed 'Mo’ Farah during the 2012 London Olympic Games. In particular, attention is given to examining how representations of Farah were related to discourses on British multiculturalism. A brief discussion of recent rejections of multiculturalism is provided, with specific reference given to political and public calls for immigrants to assimilate with 'British values'. By turning away from a dichotomous understanding of assimilation, this article suggests that processes of assimilation reflect a complicated coalescence of national inclusion and exclusion. That is, rather than simply highlighting how the national press serve to reproduce simple 'us' and 'them' binaries, this article draws upon Elias and Scotson's (1994) established-outsider perspective in order to examine how the discursive construction of the 'nation' rests upon a dynamic process of identifying and managing 'outsider' individuals. As a result, while 'outsider' groups are frequently subjected to negative media portrayals, it is argued that Farah's significance was underscored by discourses that sought to highlight his assimilated Britishness and through his promotion as a symbol of Britain’s achieved multiculturalism.
\end{abstract}

\section{Introduction}

On Day 8 (4 August) of the 2012 London Olympic Games, the Great Britain and Northern Ireland Olympic Team ('Team GB') recorded its highest gold medal tally since $1908 .{ }^{1}$ In one day of competition, gold medals were won in rowing, cycling and athletics, with the day culminating in three of the medals being achieved within 46 minutes. These medals were won by Jessica Ennis, in the women's heptathlon, Greg Rutherford, in the men's long jump and Mo Farah, in the men's 10,000 meters. ${ }^{2}$ The combined success of Ennis, Rutherford and Farah would be heralded as a significant 
moment for British multiculturalism (Allen and Blinder, 2012; Hyland, 2015; Mitra, 2014; Poulton and Maguire, 2012; Sunak and Rajeswaran, 2014; Stephens, 2015). ${ }^{3}$ Indeed, Mitra (2014) noted that:

as much as this was about being the greatest night in British athletics, as well as one of the finest ever in British sport, it was also about how the events at the Olympic stadium that night spoke to the multiculturalism and diversity that Great Britain wished the watching world to appreciate through the prism of the Olympic Games. (2014: 621)

In light of Mitra's (2014) comments, this article will critically examine British newspaper constructions of the Somali-born, British athlete, Mohamed 'Mo' Farah. Rather than simply detailing how Farah was represented within the British press, however, this article will explore how a convergence of narratives on British multiculturalism performed a particular function in the press' framing of Farah. That is, by examining how processes of acceptance, assimilation and integration were managed and negotiated within the British press, this article will expose how newspaper representations of Farah functioned to support images of Britain as a diverse, multicultural nation. Before considering this argument, the following section will discuss how processes of ambivalence and cultural differentiation have underscored post-war attitudes to British multiculturalism.

\section{'Integrate or leave': British multiculturalism, British values and the 'Muslim turn'}

Amidst growing tensions within national communities regarding immigration and multi-ethnic integration, public and political debates have frequently sought to frame multiculturalism as a failed agenda (BBC, 2015; Cameron, 2011; Chisari, 2015; Goodhart, 2013). The view that multiculturalism could function as a policy for the promotion of ethnic diversity (Parekh, 2000) has been met with criticisms that it has undermined and fragmented national cultures and shared national values (Goodhart, 2013). Indeed, while Rojek (2007) argues that 'One of the greatest challenges facing a modern British government is the task of reconciling nationalism with multiculturalism, multi-ethnicity and globalisation’ (2007: 10), Duemmler (2015) refers to an 'ambivalent logic' within approaches to civic integration (2015: 16). That is, attempts to encourage civic integration are positioned between respecting diversity 
as a constituent facet of national cohesion and perceiving integration deficits as revealing a lack of accommodation with the nation's 'core values' (Chisari, 2015; Duemmler, 2015; Gilroy, 2012; Lewis and Craig, 2014; McGhee, 2008).

Accordingly, it is the latter which has been alluded to by British Prime Minister, David Cameron, and Home Secretary, Theresa May, who have both called upon religious groups and immigrants to “embrace our British values” (Kherbane, 2014 [italics added] see BBC, 2015; Cameron, 2011). This has shifted ideological and discursive legacies of 'race' (Littler, 2005) towards disparities in the cultural differences between groups (Balibar, 2007). Under the guise of a 'common sense rhetoric' (Gilroy, 2012; Lawrence, 2005) and justified by assertions of "protecting culture”, cultural differences, such as, 'the wearing of traditional clothing, speaking another language in public, or refusing to partake in certain celebrations' are viewed as “"foreign” behaviours' and are subsequently 'met with a scornful "integrate or leave”, attitude (Kherbane, 2014).

These assertions dictate an understanding of social cohesion that rests upon particular notions of 'belonging' (Chisari, 2015). In doing so, forms of 'cultural adaptation' function as ‘a device for highlighting the illegitimacy of non-integrating behaviour' (Garner, 2010: 11). Here, (re)assertions of national identity can be read as examples of how particular groups serve to emphasise their national identity, culture and values on those who are perceived 'to be less national' (Skey, 2010: 730). Subsequently, reactions to the 2001 riots in Burnley, Oldham and Bradford resulted in the government commissioned Cantle Report arguing for immigrants to undertake an oath of allegiance to Britain (Littler and Naidoo, 2003). As noted, however, it is 'certain groups' who are perceived to be the 'problem'. Within Britain, this rhetoric has taken a decidedly ‘Muslim turn’ (Garner, 2012: 457).

For example, Macdonald (2011) has argued that 'connotations of difference' surround Muslim communities (2011: 412). This has been sustained by attempts within the British media, in particular, the British tabloid newspaper, The Sun, whose promotion of the 'poppy hijabs' was derided by Allen (2014) as a 'shrouded loyalty test' (2014). ${ }^{4}$ Similarly, in comments relating to The Sun's 'Unite against Isis' campaign, Malik (2014) argued that the campaign urged 'Muslims ... to prove their British credentials with a display of loyalty' ensuring 'that their Britishness is not taken for granted until they do so’ (2014 [italics added]). 
What is apparent from these examples is that by focusing upon a 'radicalised minority of young Muslims’ (Bryant, 2009: 7), restrictive accounts of the nation and national identity are 'not confined to the far-right' (Kassimeris and Jackson, 2015b). Instead:

the dominant understanding of Muslims through a prism of counterterrorism and the demand that British identity be promoted in order to quell Muslim violence has tacit state approval and relies on the very same discursive understandings that the EDL [English Defense League] take up - that Muslims are inherently apart from British society and that they bear full responsibility for disaffection in their communities. (Kassimeris and Jackson, 2015b)

As a consequence, the discursive construction of Muslim groups forms part of wider discussions related to community cohesion and national integration, in particular, the belief that certain 'outsiders' can adapt and assimilate with the established national community, compared to the inability of other outsider groups, in this instance, Muslim communities, who fail to integrate (Allen, 2015; Kassimeris and Jackson, 2015b; Kherbance, 2014; Lewis and Craig, 2014; Macdonald, 2011; Malik, 2014).

In short, therefore, government rhetoric has sought to direct multicultural polices towards a conditional form of national integration, based upon assimilation with British values (McGhee, 2008). Indeed, the following sections will seek to turn away from dichotomous understandings of assimilation in order to examine how processes of assimilation reflect a complicated coalescence of national inclusion and exclusion.

\section{Managing national boundaries}

For Skey (2010), forms of 'management' and 'processes of “boundary-maintenance”, rely upon 'the ability of the dominant group to define the conditions of belonging' (2010: 725). The discursive construction of national boundaries can be considered with regards to 'rhetorical function[s]' that seek to both monitor and manage those groups placed 'outside' the nation (Skey, 2010: 725). These rhetorical strategies serve to bolster 'common sense' understandings, assisting in the legitimacy of particular ideas and practices (Gilroy, 2012; Kassimeris and Jackson, 2015b; Lawrence, 2005).

Indeed, whereas, forms of 'management' are used by the British tabloid media as a discursive attempt to define the conditions of Muslim belonging within Britain 
(Allen, 2015; BBC, 2015; Kassimeris and Jackson, 2015a; 2015b; Malik, 2014), other examples of British multiculturalism can reveal a 'tokenistic' inclusion of ethnic minorities (Littler and Naidoo, 2003). Here, the 'other' is both separated 'from', but also, included 'in', constructions of the national 'us', revealing an in-between category of individuals who display, and, indeed, may even perform, all the essential characteristics deemed appropriate of a particular national group. With regards to English nationalism and the sport of cricket, Malcolm (2014) argues that:

The process of 'Othering' ... demonstrates the subtle distinctions in identities, constructing for the English not merely a dichotomous sense of 'us' and 'them', but an 'us', 'them' and an in-between category; people who in some ways are more like 'us' than 'them', but who remain, and will always remain, distinct from 'us'. (2014: 165)

This reflects a provisional and conditional acceptance of the 'other'. That is, instead of tracing how national attachments form part of a reflexive acknowledgment that sits in opposition to a restrictive, ethnocentric understanding of the nation (Beck, 2006), Skey (2014) has noted how examples of national 'reflexivity' are marked by both pragmatic and instrumental forms of cosmopolitan acceptance (See Giulianotti and Robertson, 2007; Weenink, 2008). For example, Skey (2014) highlights how 'a form of conditional cosmopolitanism' was apparent in discourses regarding the appointments of Sven Goran Eriksson and Fabio Capello as managers of the English national football team (2014: 12). ${ }^{5}$ Instead of denouncing the importance of the nation, however, there was a 'grudging acceptance of the "other"' at play (Skey, 2014: 14).

Consequently, when considered in conjunction with the literature on 'race'/ethnic relations, multiculturalism and immigration, it is apparent that there is further opportunity to explore how processes of national assimilation, within the British press, are (re)negotiated, (re)interpreted and (re)constructed through discursively identifying and monitoring the 'other'. That is, while the reproduction of 'us' and 'them' binaries can become politically charged (Wagner-Pacifici, 2010), intercultural exchanges can reveal how 'variable' and 'shifting' boundaries (Anthias, 2013) serve to identify and monitor the 'other' (Skey, 2010) through national discourses. Indeed, this requires an understanding of how processes of national reflexivity are underscored by conditional forms of acceptance (Skey, 2010; 2014). Therefore, rather than simply highlighting how the national press serve to reproduce 
simple 'us' and 'them' binaries, the following section will draw upon Elias and Scotson's (1994) established-outsider theory in order to examine how the discursive construction of the ‘nation’ rests upon a dynamic process of identifying and managing 'outsider' individuals.

\section{Monitoring and managing 'outsider' groups: exploring established-outsider relations in the British press}

The use of the established-outsider model provides a conductive framework through which processes of 'othering' can be critically considered. Rather than providing a singular analysis of race, nation or class, Elias and Scotson (1994) 'consider[ed] a broader and more pertinent causal factor that explains the process of domination and discrimination' (Loyal, 2011: 188). Accordingly, by examining the differences between a dominant ('established') and subordinate ('outsider') group in a small Leicester suburb, Elias and Scotson (1994) were able to identify a number of characteristics that served to shape the relations between each group. In part, they identified that the established group's cohesion was predicated on, and, maintained by, forms of behaviour and established networks that served to distinguish the established group as well as examples of shame and stigmatisation that signalled the outsider group as inferior (Elias and Scotson, 1994). ${ }^{6}$

Indeed, whereas Elias and Scotson (1994) did not consider 'race' relations, it is apparent that similar dynamics have been observed by Kassimeris and Jackson (2015a). They highlight how:

Racist discourse construction involves the demarcation of an in-group and an out-group, where the in-group considers itself superior and claims the right to decide who can belong, and the out-group is represented as threatening its privileges and position. (Kassimeris and Jackson, 2015a: 184-185 [italics added])

Apart from the sense of superiority that often underlies discussions on 'British values', there are important dynamics at play in the above example. Indeed, 'ingroup' and 'out-group' relations are frequently perceived through dichotomies of 'superior/inferior, responsible/irresponsible, mother/children, [and] barbarism/civilization' (Lawrence, 2005: 66). Although, these positive/negative representations serve the relational function of delineating between an 'established' 
and 'outsider' group, such dichotomies can serve to ignore the coalescent complexity of in-group and out-group relations.

For example, it has been highlighted within the literature that ethnic minorities, immigrants and refugees are frequently regarded as 'all the same' (Lawrence, 2005: 63 see Anthias and Yuval-Davis, 1992). Indeed, whereas such assertions reflect a tendency amongst established discourses to collectively stigmatise outsider individuals/groups, critically considered, they can reveal how outsider exclusion is underpinned and managed by processes of segmentation (Dunning, 2004). That is, outsider groups are divided by a segmented collection of rival subgroups, inhibiting them from maintaining the same level of social cohesion as the established. $^{7}$

Notably, this can be observed in the press' delineation between the 'good' (moderate) and 'bad' (terrorist) Muslim (Macdonald, 2011; Sartawi and Sammut, 2012; Schirmer et al., 2012) as well as in the mediated portrayal of the British Asian boxer, Amir Khan. Khan's media image reflected a 'masculine ideal that all British Asian, particularly Muslim, men should aspire to' (Lawrence, 2011: 119). As a result, by:

promoting Khan as a bench-mark and role model ... British Asian males who resemble Khan in his attitude toward nationalism and moral values ... are considered 'with us' (but importantly, still not quite 'us'), whilst those who are unable (or refuse) to resemble his media persona are positioned as obdurately 'against us'. (Lawrence, 2011: 119)

Consequently, although ethnic minorities are often subjected to forms of exclusion, the above example reveals how 'certain' outsiders can be discursively managed as part of the established 'us'. This suggests that if 'boundaries are continuously negotiated, since social actors engage in struggles over social categories and distinctions' (Duemmler, 2015: 4), then certain 'outsiders' may negotiate their position, by presenting and adapting their behaviour in particular ways in order to gain access to established domains (Maguire and Mansfield, 1998). ${ }^{8}$

To this extent, whereas critical discussions on multiculturalism often fall foul of propagating opposing assessments of British society as either ethnically diverse or cohesively deficient (Goodhart, 2013; Modood, 2007) and while multicultural polices within Britain have been undermined by an incentive to promote 'British values', this article would argue that 'recognition and belonging and the unequal relations of 
power that exist in the attribution and acceptance of identity claims' (Skey, 2010: 718-719) forms an important part of debates on immigration, British multiculturalism and 'British values' (Lewis and Craig, 2014).

Subsequently, rather than accentuating a homogenous portrayal of ethnic minority and immigrant communities, examples of segmentation in the mediated representation of 'outsider' groups can assist the assimilation of 'certain' outsiders, a process that correspondingly supports established images of the nation (Engh et al., 2014; Falcous and Silk, 2010; Fortier, 2005). Viewed through an established-outsider lens, it is apparent that these debates, and national belonging in general, point towards the discursive management of outsider groups through established discourses.

For the purpose of this article, these discourses will be used to explore how Farah's 'outsider' status was discursively managed and incorporated as part of 'established' national discourses within the British press. Indeed, despite the fact that 'Mo is an abbreviation of Mohammad, amongst the most common Islamic names in the world' and 'a devout Muslim who prays before his races' (Mitra, 2014: 621), Farah's Olympic success ‘emerged as central to ideas about British identity in cosmopolitan times of austerity' (Stephens, 2015: 8-9). Accordingly, the mediated representation of Mo Farah provides a valuable opportunity to critically explore the relationship between British multiculturalism and British identity in 2012. By examining how 'established and conventional symbolic patterns' (Smith and Phillips, 2006: 820) were used to frame Farah within the British press, one can identify how the media 'wield considerable influence through ideologically infused discourses' (Burroughs, 2014: 166) that reflect and reinforce the views and opinions of established groups. The following sections will briefly outline how these dynamics can be examined in relation to the British press.

\section{Method}

To reiterate, this article critically examined the construction, framing and representation of Mo Farah in British newspaper coverage of the 2012 London Olympic Games. Newspaper articles were drawn from a cohort that included; the Daily Mail, The Daily Telegraph, Daily Mirror, The Independent, The Herald, the Belfast Telegraph and the Western Mail (including Sunday editions). ${ }^{9}$ In total, 51 articles were selected from the 5 August to 13 August 2012. This sample range 
included coverage from the day after Farah’s first Olympic gold medal (04/08/12) up until two days after his second gold medal (11/08/12). An inductive examination of selected articles was conducted via a qualitative thematic analysis (Altheide and Schneider, 2013). This involved a process of open and axial coding whereby important themes, trends and patterns related to the framing of Farah as well as British multiculturalism were identified. The following sections will explore these themes in closer detail.

\section{Framing Farah: 'a child from Somalia'}

In an interview with Farah, Hattenstone (2012) has noted that 'The most common myth' surrounding his background 'is that he came [to Britain] as an asylum seeker' (2012). ${ }^{10}$ This myth was perpetuated by numerous reports that referred to Farah's arrival in 'London as an asylum-seeker' and a refugee (Milmo, 2012, The Independent, 11/08/12 see Daily Mail, 2012; Dunn, 2012; Izzard, 2012; Miliband, 2012; White, 2012). Farah's arrival in 'Britain as an eight-year old from Somalia' (The Western Mail, 06/08/12) was not only marked by a lack of biographical accuracy, however, but also by narratives that sought to recite his journey to Britain as one marked by both danger and 'escape' (Lawton, 2012b). Here, press reports highlighted how Farah 'was driven out of his homeland of Somalia by a cruel civil war' (Bannister, The Mail on Sunday, 12/08/12). Amidst, a ‘collapsing Somalia' (Peck, The Independent, 13/08/12), Garside (2012) added that 'Farah's life chances in war-torn Somalia were less than auspicious’ (The Independent, 06/08/12).

In fact, Farah's birthplace was unavoidable within the press' coverage. Gallagher (2012) argued that 'Team GB's' 'Super Saturday' was a 'night that belonged to Somalian-born Farah' (The Mail on Sunday, 12/08/12). Macwhirter (2012), writing in the Sunday Herald, and Beacom (2012), writing in the Belfast Telegraph, referred to Farah as 'from Somalia' (Macwhirter, Sunday Herald, 12/08/12) and the 'child from Somalia' (Beacom, Belfast Telegraph, 06/08/12). Loxton (2012) noted that 'Somalia-born Farah's stunning win put the golden seal on the last full day of the Games' (Sunday Herald, 12/08/12 [italics added]), whereas other reports referenced Farah's arrival from the Somali capital, Mogadishu (Holt, 2012; Peck, 2012). 
As can be seen, Farah's 'outsider' Somali-heritage was routinely acknowledged within the British press via discourses that sought to highlight his 'difference' (Engh et al., 2013), most notably, his inability to speak English. Accordingly, Moreton (2012) noted that when Farah arrived in Britain he was 'unable to speak a word of English' (The Sunday Telegraph, 12/08/12). Indeed, language is an important signifier in discussions relating to British social cohesion and identification. An inability to speak English is often 'evidence of inferiority' (Lawrence, 2005: 71). In the case of Farah, however, these narratives were discursively related to Farah's efforts to integrate with British society. Here, 'subjective and political questions of what immigrants are supposed to do in order to integrate' (Garner, 2010: 449 [italics added]) were underscored by Garside (2012), who commented that 'when he [Farah] pitched up, aged eight, in the great melting pot that is this sceptred isle, speaking barely a word of English, he still had it all to do' (Garside, The Independent, 06/08/12 [italics added]).

What is apparent from the above examples is the degree to which Farah's sporting achievements were used as a way of presenting his assimilation with British society. Significantly, it was Farah who 'had it all to do' (Garside, The Independent, 06/08/12), an undertaking that was emphasised by the fact that Farah had now become British. Subsequently, in conjunction with his arrival in the UK, Randall and Dugan (2012) stated that 'Mo Farah, the man who warmed to Britain from the time he arrived here as a child from Somalia, has now been in turn embraced by the whole country' (The Independent on Sunday, 12/08/12 [italics added]). In addition, Lawton (2012b) highlighted that Farah's pride in competing for Britain reflected 'a man who escaped as a boy from one of the most hazardous parts of Africa and made a new life in a country which is now trying to measure that pride that now comes when it claims him for its own' (The Independent on Sunday, 12/08/12 [italics added]). As can be seen from these examples, it was only after Farah's success that the nation could 'now' begin to embrace him.

This was, however, a negotiated acceptance, indeed, one that stood between Farah's national embracement and his Somali-heritage. That is, in the same way that in France skin colour, culture, religion and nationality remain an important part of the 'otherness' of minority groups (Zimmerman, 2014), Farah's 'otherness' remained embedded within his immigrant 'story' (Mitra, 2014). As a result, Farah’s ‘otherness' was not erased (Hyland, 2014), but instead, became an important signifier in the 
press' narrative. In the same way that '[Jesse] Owens was always denoted as a black athlete' and '[Kathy] Freeman [was] always an Aboriginal sprinter' (Hyland, 2014: 272), Farah was continually represented as a ‘Somali born’ British athlete (Dunn, 2012; Peck, 2012; Randall and Dugan, 2012).

This suggests that narratives of 'inclusion' and 'exclusion' are complicated processes. Here, 'inclusion' is not simply achieved or unquestionably accepted but is instead constrained by balances of power and established-outsider dynamics. That is, while the above examples have highlighted how it is the point of origin that takes precedent in the construction of diasporic communities (Anthias, 2001 see Beacom, 2012; Gallagher, 2012; Loxton, 2012; Macwhirter, 2012), the inclusion of ethnic minorities is also predicated on their ability to declare and confirm their attachment to the host nation. The following section will consider this in further detail.

\section{'This is my country': belonging and loyalty in the British press}

Fortier (2005) has examined how ethnic minorities are continually obliged to 'hail' their Britishness (2005: 571). Accordingly, Alibhai-Brown (2012) highlighted:

Today Mo, while remaining a devout Muslim, extols his adopted country. When he was asked last week after his victory in the 10,000 metres if he'd rather be representing Somalia, his simple response spoke volumes. 'Not at all, mate. This is my country'. His joyful embrace of Britishness, replicated by other British Olympians of immigrant stock, has aroused the same rapturous feelings of pride in people who, until now, were wary of nationalistic celebrations and expressions - including me. (Daily Mail, 13/08/12 see Crompton, 2012)

The above remarks reveal a number of important significances in the framing of Farah.

First, Farah's refusal to adopt his Somali heritage echoes previous British athletes whose uncritical attachment to Britain allowed them to be accepted by the nation (Carrington and McDonald, 2001; Fortier, 2005). Second, whereas the British press sought to continually (re)define Farah as once 'Somalian’ but now 'British', it was evident that immigrant 'outsiders' were required to prove their Britishness by openly demonstrating their identification with British culture. ${ }^{11}$ In fact, Macdonald (2011) has noted how 'Questions of "belonging” morp[h] insidiously into questionings of “loyalty”' (2011: 412). Accordingly, the need for Farah to 'confirm' 
his Britishness echoed Fortier's (2005) comments regarding the need for 'black and Asian Britons ... to be accountable, to declare their attachment to Britain and to silence any anger or critique' in order to be 'recognized as legitimate subjects' (2005: 571 see Ahmed, 2000). This was emphasised by 'Farah ... [who] spelled out his pride at winning gold for Great Britain’ (The Western Mail, 06/08/12 see Moreton, 2012). For former British Olympian, Sir Roger Bannister, 'Farah, ... whole-heartedly espoused Britain as his country, declaring patriotically: "Britain is my country. This is my home.”' (The Mail on Sunday, 12/08/12). In doing so, Bannister (2012) added that Farah reflected 'the spirit we want to encourage. And how admirably, how graciously, and with what quiet dignity, Farah has displayed it.' (The Mail on Sunday, 12/08/12 [italics added]).

Indeed, these comments derive particular significance when compared with pre-Olympic concerns regarding the eligibility of certain members of 'Team GB', dubbed 'plastic Brits' within the media (Poulton and Maguire, 2012). Poulton and Maguire (2012) note that:

The 'plastic Brit' narrative can thus be read as an insight into right-wing perceptions about Britain and 'Britishness' and underscored by an antimulticulturalism that struggles to celebrate dual-nationals as truly one of us. (2012: 11)

Furthermore, the 'plastic Brit' label can be seen as a narrative device, from which examples of segmentation could be identified within the press' coverage. As previously noted, it was Farah's 'spirit' that was singled out by Bannister (2012) as an encouraging aspect of Farah’s personality. Similarly, Lawton (2012a) noted:

But there was another wonder and it is one which should never be forgotten when we consider the value of encouraging the potential of the best of our youth and as enshrined by the magnificent Mo Farah, the spirit of those who come among us seeking a better, more secure life and to which they are ready to donate the greatest of their talent and ambition. (The Independent, 06/08/12a [italics added])

In fact, Farah's 'donated' talent was underscored by comparing 'his story' with the ‘opportunism' of the Anguillan-born, Shara Proctor. Here, Samuel (2012) argued that:

Mo Farah represents the best of modern Britain and his story could not be further removed from the opportunism that is becoming increasingly prevalent in modern international sport. Not to mention colonialism. I still do not think 
it is fair that Shara Proctor has to compete for Great Britain, because Anguilla, her country of origin, is not recognised by the International Olympic Committee. South Sudan is not a member either, but its marathon man Guor Marial ran beneath an IOC banner yesterday. Why is Proctor different? And why aren't the Princess Royal, Lord Coe and all our other heavyweights on the Olympic stage not lobbying ferociously for Anguilla and other British overseas territories to be given their due? Grenada declared a national holiday on the occasion of their first gold medallist, 400m runner Kirani James, last week. If Proctor had been the best long jumper at these Games, Anguilla would have been denied that nationally uplifting moment. Aren't the days of empire over? (Daily Mail, 13/08/12)

In contrast to Procter, Farah was positively reinforced as a symbol of the 'right' type of assimilated immigrant, with the 'right' type of behaviour (Bannister, 2012) and with a story that was apparently more convincing than Procter's opportunism.

In contrast, therefore, 'Farah ... represent[ed] a new kind of national hero' (Milmo, The Independent, 11/08/12), who had provided a “"Land of Hope and Glory” occasion' (Turnball, The Independent, 11/08/12) that confirmed 'his place among the immortals of British sport' (Gallagher, The Mail on Sunday, 12/08/12). By highlighting Farah's public attachment to Britain (Alibhai-Brown, 2012; Crompton, 2012; Samuel, 2012) as well as his British confirmations (Alibhai-Brown, 2012), Farah could be incorporated 'within' the nation (Bannister, 2012). Whereas Farah's inability to speak English was noted, his Britishness was confirmed via references to his acquired 'London accent' (Moreton, 2012; Peck, 2012; The Western Mail, 2012) and by Beacom's (2012) assertion that Farah was 'as British as fish and chips' (Belfast Telegraph, 06/08/12).

Indeed, the dissection of Farah's British characteristics was given further emphasis by the English comedian, Edward 'Eddie’ Izzard, who made note of Farah’s 'typically humble, British way’ (Daily Mirror, 13/08/12). This was supported with descriptions that sought to associate Farah's success with the British Union flag. A familiar trope within media discourses (Burdsey, 2007), it was noted, during Farah's post-race celebrations, that he held 'the Union Flag aloft' (Harrison, Sunday Herald, 05/08/12 see Mendick, 2012). In fact, while 'carefully wrapping himself in the Union flag' (Lawton, The Independent on Sunday, 12/08/12b see Crompton, 2012) Farah was heralded as a 'Britain' who 'had given him[self] and his wife and his joyfully celebrating young daughter, a new future, a new chance' (Lawton, The Independent, 06/08/12a). Aside from the fact that Farah met his wife and adopted his daughter some years after his arrival in Britain, it was apparent that Farah's 'British' image 
served to confirm British multiculturalism by helping to signify Britain's successful multicultural society. The effects of this will now be considered.

\section{'An affirmation of who we are': framing Farah as a symbol of British multiculturalism}

In conjunction with the press' framing of Farah, reports on Britain were notably positive, with certain suggestions that a new and more confident Britain had been displayed during the games (Black, 2015). Peck (2012) argued that:

If we truly have all found the past 50 years so confusing, £9bn might just prove to be a cheap price to pay for an affirmation of who we are, when thousands in the stadium and millions in their living rooms were delivered to a place near euphoria, by a man who was brought here from Somalia as a little boy, by his desperate parents, and who talks like a Londonder and runs like the wind. (The Independent, 13/0812)

Here, Farah's successful integration served to construct an understanding of Britain 'as being developmental, multicultural and progressive' (Engh et al., 2014: 785). Indeed, such constructions can form part of a wider 'developmental discourse' in established nations (Engh et al., 2014). Fortier (2005) has noted how the conditional inclusion of ethnic minorities can serve to represent the nation 'as a tolerant and inclusive society’ (2005: 569 see Falcous and Silk, 2010). ${ }^{12}$ Consequently, this was echoed by Hart (2012) who noted that, 'As a Somali by birth and a Londoner since he was eight years old, Farah is not just the world's greatest long-distance runner but a potent symbol of the city's diversity' (The Daily Telegraph, 12/08/12). To this extent, Farah's success was also used to underscore examples of successful British aspiration. Garside (2012) stated that 'The Olympics is writing a parable for the modern age, recycling grand notions of equality and opportunity and rolling them out across one great meritocratic canvas' (The Independent, 06/08/12). Accordingly, by working 'his way up through the state school system', Farah, 'The skinny kid who arrived in Britain unable to speak English has the ear and attention of the powerful' (Milmo, The Independent, 11/08/12).

With regards to the acceptance of outsider groups, Engh et al. (2013) note that while 'Partial access and inclusion is granted to outsiders' such inclusion is predicated 'on conditions given by the established ... so as to serve the established group' (2013: 
793). Here, the image of sporting celebrities can be used to help bolster 'the existence of a relatively democratic social system’ (Malcolm, 2012: 1079). As a result, ‘ideas about striving, working hard and playing by the rules temporarily stuck to images of Farah’s highly athletic body’ (Stephens, 2015: 9). However, whereas previous work has noted that the mediated representation of the English cricketer, Andrew 'Freddie' Flintoff, functioned to highlight his 'work ethic', confirming that 'human agency was the primary determinant of an individual's social condition' (Malcolm, 2012: 1079), Farah's success was predicated on the 'tolerant' British society he had grown up in. White (2012) exclaimed that 'anyone from any minority can succeed in a country as tolerant as this' (The Daily Telegraph, 06/08/12). In such instances, Farah’s successful 'assimilation' was viewed 'as a force of Britishness' (Fortier, 2005: 560) and a key factor in his Olympic success. Echoing Fortier (2005), 'Farah hailed the role of Britain's multicultural society in helping him to his double gold medal Olympic performance, saying it provided him with the opportunity to shine' (The Independent, 13/08/12).

Consequently, rather than simply viewing assimilation as an 'outsider' group copying and appropriating 'established' behaviours and values, assimilation can be used as signifier of, and, indeed, a positive characteristic for, 'established' groups who have successfully managed to include former 'outsiders' (Engh et al., 2014). This is echoed in Canada, whereby the permeability of boundaries between an established group - the national 'imagined community' - and perceived outsiders immigrant, refugee, asylum seekers - serves to support Canada's global image (Mensah, 2014). Indeed, Mensah (2014) notes that:

Through this selection and absorption process, Canada is able to boost the sense of compassion and cosmopolitanism among its citizens and to sustain its international image as a caring, humanitarian nation (2014: 291-92)

Similarly, during the London games, the press' framing of Britain's multicultural pride, tolerance and inclusivity served to bolster its established image as a progressive, meritocratic multicultural nation state. Indeed, Farah's migrant 'story' (Mitra, 2014) was 'a truly uplifting tale' that functioned to represent 'Britain at its multicultural, inclusive best’ (Dunn, Sunday Mirror, 12/08/12). Ultimately, Farah provided ‘a celebration of multicultural Britain’ (Holt, Daily Mirror, 13/08/12), which 
delivered a resounding confirmation of Britain's multicultural ambitions (Falcous and Silk, 2010).

\section{Conclusion}

Rojek (2007) has noted that 'Multiculturalism suggests that people do not merely have different identities, but that these identities are positioned in various ways in relation to "the nation"' (2007: 33). Accordingly, this article has examined how mediated debates on British multiculturalism were positioned in relation to British newspaper discourses on Mo Farah. Significantly, the findings presented in this article expose how 'outsider' individuals, such as, Farah, were 'accepted' by the British press. Here, the positioning of Farah, within newspaper discourses, exposed how ethnic minority athletes are provided a 'degree of difference' (Skey, 2014) when 'positioned ... in relation to "the nation”' (Rojek, 2007: 33).

Accordingly, despite the fact that Farah was declared to be 'as British as fish and chips' (Beacom, Belfast Telegraph, 06/08/12) notions of difference were maintained via frequent references to his Somali birth and his inability to speak English (Gallagher, 2012; Loxton, 2012; Macwhirter, 2012; Moreton, 2012). As a result, Farah's Britishness was confirmed by his decision to race for his 'adopted' nation as opposed to Somalia (Alibhai-Brown, 2012; Bannister, 2012; Crompton, 2012; Samuel, 2012). Here, it is evident that outsider groups maintain a liminal space within newspaper discourses (Fortier, 2005). That is, British acceptance was something that had to be achieved, debated and performed, indeed, a process that paradoxically served to re-define Farah as 'different'.

This suggests that the ability of established groups to allow certain 'outsiders' to become part of established discourses is often 'contingent on them toeing the line(s) in several ways ... as "appropriate” national subjects' (Falcous and Silk, 2010: 172). Furthermore, whereas it has been identified how processes of stigmatisation and exclusion can help to maintain the boundaries between groups (Engh et al., 2014), the press' framing of Farah reveals how, in certain instances, established groups can adopt 'particular' outsiders (Piwoni, 2015). In doing so, Farah's ‘success ... made him a poster-boy for multicultural Britain’ (Milmo, The Independent, 11/08/12). The British press' framing of Farah provided the benefit of promoting a positive image of Britain as an established multicultural nation. In doing so, the 'negotiated' acceptance 
of Farah, within British newspaper discourses, provided the opportunity for Britain to uphold its positive self-image, indeed, a positive 'we-identity' (Elias and Scotson, 1994; Hart, 2012; Milmo, 2012; The Independent, 2012).

In conjunction with Skey's (2014) assertion that 'the nation is still used as a routine framing device through which to understand the significance of key actors' (2014: 10), the findings presented in this article indicate how this 'understanding', is predicated on the discursive construction of established-outsider relations. As a result, while 'outsider' groups are frequently subjected to negative media portrayals, Farah's significance was underscored by his assimilated Britishness and through his promotion as a symbol of Britain's achieved multiculturalism. Consequently, in contrast to criticisms that have stressed the failure of British multiculturalism (Goodhart, 2013), newspaper representations of Farah functioned to effectively 'reanimate' (Allen, 2015) British multiculturalism by highlighting Farah's successful integration. In short, it was Farah who provided the 'affirmation of who we are' (Peck, The Independent, 13/05/15 [italics added]).

\section{References}

Ahmed S (2000) Strange Encounters. Embodied Others in Postcoloniality. London: Routledge. Allen C (2015) A Critical Analysis of Britain’s Living, Dead and Zombie Multiculturalism: From 7/7 to the London 2012 Olympic Games. Social Sciences 4: 18-33.

Allen C (2014) The poppy hijab is just Islamophobia with a floral motif. Available at: http://www.newstatesman.com/politics/2014/11/poppy-hijab-just-islamophobia-floral-motif Allen W, and Blinder S (2012) Jessica Ennis, Mo Farah and Identity Language in the British Press: A Case Study in Monitoring and Analysing Print Media. Migration Observatory Report, COMPAS, December.

Altheide DL, and Schneider, CJ (2013) Qualitative Media Analysis. L.A.: Sage.

Anthias F (2013) Moving beyond the Janus face of integration and diversity discourses: towards an intersectional framing. The Sociological Review 61: 323-43.

Anthias F (2001) The concept of “social division” and theorising social stratification: looking at ethnicity and class. Sociology 35(4): 835-54.

Anthias F, and Yuval-Davis N (1992) Racialized Boundaries: Race, Nation, Gender, Colour and Class and the Anti-Racist Struggle. London: Routledge.

Balibar E (2007) Is there a “Neo-Racism”? In: Gupta TD, James CE, Maaka RC, Galabuzi GE, and Andersen C (eds) Race and Racialization: Essential Readings. Toronto: Canadian Scholars' Press Inc, 83-88.

Bannister R (2012) These remarkable Games have filled my heart with pride. It is as if the golden age of my youth had never gone away. The Mail on Sunday, 12/08/12. 
BBC (2015) Theresa May says UK will not tolerate extremists. Available at:

http://www.bbc.co.uk/news/uk-32013794

Beacom S (2012) Saturday Night Fever. Belfast Telegraph, 06/08/12.

Beck U (2006) Cosmopolitan Vision. Cambridge: Polity Press.

Black J (2015) Portraying Britain’s Past: English National Newspaper Coverage of the 2012 London Olympic Ceremonies. In: Poynter G, Viehoff V, and Li Y (eds) The London Olympics and Urban Development: The Mega-Event City. London: Routledge.

Bryant C (2009) The British Question. British Politics Review 4(3): 6-7.

Burdsey D (2007) Role with the punches: The construction and representation of Amir Khan as a role model for multiethnic Britain. The Sociological Review 55(3): 611-13.

Burroughs E (2014) Discursive representations of ‘illegal immigration’ in the Irish newsprint media: The domination and multiple facets of the 'control' argumentation. Discourse \& Society 26(2): 165183.

Cameron D (2011) PM's speech at Munich Security Conference. Available at: https://www.gov.uk/government/speeches/pms-speech-at-munich-security-conference

Carrington B, and McDonald I (2001) 'Race', Sport and British Society. London: Routledge.

Chisari M (2015) Testing citizen identities: Australian migrants and the Australian values debate.

Social Identities: Journal for the Study of Race, Nation and Culture 00: 1-17.

Crompton S (2012) The new country that we could be. Daily Telegraph, 11/08/12.

Daily Mail (2012) Now deliver the legacy these games deserve. 11/08/12.

Duemmler K (2015) The exclusionary side effects of the civic integration paradigm: boundary processes among youth in Swiss schools. Identities: Global Studies in Culture and Power 00: 1-19.

Dunn A (2012) Poetry in Motion! Sunday Mirror, 12/08/12.

Dunning E (1999) Sport Matters. London: Routledge.

Dunning E (2004) Aspects of the figurational dynamics of racial stratification: a conceptual discussion and developmental analysis of black-white relations in the United States. In: Loyal S, and Quilley S (eds) The Sociology of Nobert Elias. Cambridge: Cambridge University Press, 75-94.

Dunning E, and Hughes J (2013) Norbert Elias and Modern Sociology: Knowledge, Interdependence, Power, Process. London: Bloomsbury.

Elias N, and Scotson JL (1994) The Established and the Outsiders: A Sociological Enquiry into Community Problems. London: SAGE.

Engh MH, Agergaard S, and Maguire J (2013) Established - outsider relations in youth football tournaments: an exploration of transnational power figurations between Scandinavian organizers and African teams. Soccer \& Society 14(6): 781-98.

Falcous M, and Silk ML (2010) Olympic Bidding, Multicultural Nationalism,Terror, and the Epistemological Violence of 'Making Britain Proud'. Studies in Ethnicity and Nationalism 10(2): 16786.

Fortier AM (2005) Pride politics and multiculturalist citizenship. Ethnic and Racial Studies 28(3): 55978. 
Gallagher I (2012) Chariots of Farah! Mo leads charge on Super Saturday II. The Mail on Sunday, $12 / 08 / 12$.

Garner S (2012) A moral economy of whiteness: Behaviours, belonging and Britishness. Ethnicities 12(4): 445-64.

Garner S (2010) The entitled nation: how people make themselves white in contemporary England. Available at: http://www.sens-public.org/article.php3?id_article=729

Garside K (2012) These games are writing a parable for modern Britain, of equality and opportunity. The Independent, 06/08/12.

Gilroy P (2012) 'My Britain is fuck all’ zombie multiculturalism and the race politics of citizenship. Identities: Global Studies in Culture and Power 19(4): 380-97.

Gilroy P (2005) Postcolonial Melancholia. New York: Columbia University Press.

Giulianotti R, and Robertson R (2007) Recovering the social: globalization, football and transnationalism. Global Networks 7(2): 166-86.

Goodhart D (2013) The British Dream: Successes and Failures of Post-war Immigration. London: Atlantic Books.

Goudsblom J (1977) Sociology in the Balance: A Critical Essay. New York: Columbia University Press.

Harrison J (2012) Fantastic Farah ends long wait. Sunday Herald, 05/08/12.

Hart S (2012) Farah's incredible golden double. The Sunday Telegraph, 12/08/12.

Hattenstone S (2012). What drives Mo Farah? Available at:

http://www.theguardian.com/sport/2012/dec/07/what-drives-mo-farah-interview

Holt O (2012) Best.. By Farah. The Mirror, 13/08/12.

Hyland N (2014) Bolt and The Beast: Representing Reality and Keeping It Real in London 2012. Text and Performance Quarterly 34(3): 267-85.

Izzard E (2012) In These Games I've Felt So Proud to Be British... Daily Mirror, 13/08/12.

Kassimeris G, and Jackson L (2015a) The Ideology and Discourse of the English Defence League:

'Not Racist, Not Violent, Just No Longer Silent'. The British Journal of Politics and International Relations 17: 171-88.

Kassimeris G, and Jackson L (2015b) The English Defence League’s 'rational Islamophobia' is a racist discourse, but it is not confined to the EDL. Available at: http://blogs.lse.ac.uk/politicsandpolicy/notracist-not-violent-just-no-longer-silent-is-the-edl-racist/

Kherbane R (2014) Enforcing “British values” is a convenient pretext for casual xenophobia and bigotry. Available at: http://www.newstatesman.com/politics/2014/12/enforcing-british-valuesconvenient-pretext-casual-xenophobia-and-bigotry

Lawrence E (2005) Just plain common sense: the 'roots’ of racism. In: Centre for Contemporary Cultura Studies (ed) The Empire Strikes Back: Race and Racism in 70s Britain. London; New York: Routledge, 45-92.

Lawrence S (2011) Representation, Racialisation and Responsibility: Male Athletic Bodies in the (British) Sports and Leisure Media. In: Watson B, and Harpin J (eds) Identities, Cultures and Voices in Leisure and Sport. Eastbourne: Antony Rowe, 93-108. 
Lawton J (2012a) The finest night in British sport. The Independent, 06/08/12.

Lawton J (2012b) Brave triumph that moved the very heart of a nation. The Independent on Sunday, $12 / 08 / 12$.

Lever J, and Milbourne P (2014) Migrant workers and migrant entrepreneurs: changing established/ outsider relations across society and space? Space and Polity 18(3): 255-68.

Lewis H, and Craig G (2014) 'Multiculturalism is never talked about': community cohesion and local policy contradictions in England. Policy \& Politics 42(1): 21-38.

Littler J (2005) Introduction: British Heritage and the Legacies of 'Race'. In: Littler J, and Naidoo R (eds) The Politics of Heritage: The Legacies of 'Race'. London: Routledge, 1-20.

Littler J, and Naidoo R (2003) White Past, Multicultural Present: Heritage and National Stories. In: Brocklehurst H, and Phillips, R (eds) History, Nationhood and the Question of Britain. London: Palgrave Macmillan.

Loxton R (2012) Super Saturday mark II as Farah leads Team GB's late gold rush. Sunday Herald, $12 / 08 / 12$.

Loyal S (2011) A land of a hundred thousand welcomes? Understanding established and outsiders relations in Ireland. The Sociological Review 59(S1): 181-201.

Macdonald M (2011) British Muslims, memory and identity: Representations in British film and television documentary. European Journal of Cultural Studies 14(4): 411-27.

Macwhirter I (2012) Identity Crisis. Sunday Herald, 12/08/12.

Maguire J, and Mansfield L (1998) No-Body’s Perfect: Women, aerobics and the body beautiful. Sociology of Sport Journal 15(2): 109-37.

Malcolm D (2012) Figuring Freddie: Andrew Flintoff, the Ashes and English national identity. Sport in Society: Cultures, Commerce, Media, Politics 15(8): 1070-85.

Malcolm D (2014) Globalizing Cricket: Englishness, Empire and Identity. London: Bloomsbury. Malik N (2014) The Sun’s 'Unite against Isis’ campaign is a proxy for anti-Muslim bigotry. Available at: http://www.theguardian.com/commentisfree/2014/oct/08/sun-unite-against-isis-muslim-bigotry

McGhee D (2008) The End of Multiculturalism? Terrorism, Integration and Human Rights.

Maidenhead: Open University Press.

Mendick R (2012) Farah's astonishing path to Olympic champion. The Sunday Telegraph, 05/08/12.

Mensah J (2014) The Black, continental African presence and the nation-immigration dialectic in

Canada. Social Identities: Journal for the Study of Race, Nation and Culture 20(4-5): 279-98.

Miliband E (2012) The Games have given us a glimpse of the country we can be. The Sunday

Telegraph, 12/08/12.

Milmo C (2012) Devout Farah stands on the edge of greatness. The Independent, 11/08/12.

Mitra S (2014) London 2012: multiculturalism, diversity and the Indian perspective. Sport in Society:

Cultures, Commerce, Media, Politics 17(5): 617-27.

Modood T (2007) Multiculturalism. Cambridge: Polity Press.

Moreton C (2012) Crowd rises for our greatest athlete in the greatest games. The Sunday Telegraph, $12 / 08 / 12$. 
Parekh B (2000) Report of the Commission on the Future of Multi-ethnic Britain. London:

Profile/Runnymede Trust.

Peck T (2012) Where it all began... The Independent, 13/08/12.

Piwoni E (2015) Claiming the nation for the people: the dynamics of representation in German public discourse about immigrant integration. Nations and Nationalism 21(1): 83-101.

Poulton E, and Maguire J (2012) 'Plastic' or 'Fantastic' Brits? Identity Politics and English Media Representations of 'Team GB' during London 2012. JOMEC Journal: Journalism, Media and Cultural Studies, November (2).

Randall D, and Dugan E (2012) Farah seizes glory for Team GB with stunning victory. The Independent on Sunday, 12/08/12.

Rojek C (2007) Brit-myth: Who Do the British Think They Are? London: Reaktion Books. Samuel M (2012) My final word on the plastic Brits (for now). Daily Mail, 13/08/12.

Sartawi M, and Sammut G (2012) Negotiating British Muslim identity: Everyday concerns of practicing Muslims in London. Culture \& Psychology 18(4): 559-76.

Schirmer W, Weidenstedt L, and Reich W (2012) From tolerance to respect in inter-ethnic contexts. Journal of Ethnic and Migration Studies 38: 1049-65.

Skey M (2010) 'A sense of where you belong in the world': national belonging, ontological security and the status of the ethnic majority in England. Nations and Nationalism 16(4): 715-33.

Skey M (2014) 'What nationality he is doesn't matter a damn!' International football, mediated identities and conditional cosmopolitanism. National Identities 00: 1-17.

Smith P, and Phillips T (2006) Collective belonging and mass media consumption: unraveling how technological medium and cultural genre shape the national imaginings of Australians. The Sociological Review 54(4): 818-46.

Stephens AC (2015) The affective atmospheres of nationalism. Cultural Geographies 00: 1-18.

Sunak R, and Rajeswaran S (2014) A Potrait of Modern Britain. London: Policy Exchange.

The Independent (2012) Farah thanks multicultural Britain for his second chance. 13/08/12.

The Western Mail (2012) Seb backs Farah to complete big double. 06/08/12.

Turnball S (2012) Can Mo follow Bolt to double joy? The Independent, 11/08/12.

Wagner-Pacifici R (2010) Theorizing the Restlessness of Events. American Journal of Sociology 115(5): 1351-86.

Weenink D (2008) Cosmopolitanism as a Form of Capital: Parents Preparing their Children for a Globalizing World. Sociology 42(6): 1089-1106.

White J (2012) Raining medals on golden weekend that put the Great back into Britain. The Daily Telegraph, 06/08/12.

Zimmerman DD (2014) Young Muslim women in the United States: identities at the intersection of group membership and multiple individualities. Social Identities: Journal for the Study of Race, Nation and Culture 20(4-5): 299-313.

\section{Notes}


${ }^{1}$ At the 1908 London Olympic Games, 'Great Britain and Ireland' also achieved six gold medals. In 1908, however, the 'Great Britain and Ireland' team included athletes from both Northern Ireland and the Republic of Ireland. At the time, an un-separated Ireland formed part of the UK. The Republic of Ireland would compete as a separate Olympic team at the 1924 Paris Olympic Games. Today, there remains controversy over the 'Team GB' team name due to the fact that it fails to include Northern Ireland in its title and branding. 'Great Britain' collaboratively refers to England, Scotland and Wales, and not, Northern Ireland.

${ }^{2}$ Mo Farah would go on to win a second gold medal in the men's 5,000m. The final was held on 11 August 2012.

${ }^{3}$ Jessica Ennis's mother is white British and her father is of Jamaican/Afro-Caribbean origin. Greg Rutherford is white British.

${ }^{4}$ The Hijab is a veil worn by Muslim women. In 2014 a fashion designer created a Hijab decorated in the red Poppy flower, a symbol wartime remembrance. The Hijab's were created to commemorate the first Muslim soldier who received the Victoria Cross.

${ }^{5}$ In this instance, the appointment of a foreign manager was based upon the condition of ensuring the success of the English national football team.

${ }^{6}$ Despite the fact that each group was 'identical in terms of the conventional indices of social stratification ... a whole constellation of symptoms usually associated with class exploitation and social oppression was detectable in the relations between them' (Dunning and Hughes, 2013: 63). Here, 'Exclusion and stigmatisation of the outsiders by the established group, ... were two powerful weapons used by the latter to maintain their identity, to assert their superiority, keeping the others firmly in their place' (Elias and Scotson, 1994: xviii). One important method that was used to exclude and stigmatise the outsider groups was gossip, which helped to encourage feelings of group superiority and inferiority.

${ }^{7}$ Indeed, Lever and Milbourne (2014) examined the experiences of migrant workers in Wales, noting that segregated working practices confounded problems for migrant workers by maintaining their position as outsiders. Here, 'a policy of divide and rule, whereby any gains each group could potentially obtain collectively ... [were] undermined by enforced intragroup competition' (Lever and Milbourne, 2014: 261). At the same time, however, forms of segmental solidarity can serve to unite outsider groups under variants of 'ordered segmentation' (Dunning, 1999).

${ }^{8}$ Lever and Milbourne (2014) have highlighted how 'the relational dynamics of new forms of European migration' had an impact on established-outsider dynamics within Wales (2014: 257). Here they noted 'that entrepreneurship amongst migrant workers is having an impact on the affective experiences of established populations and reshaping established/outsider relations across society and space' (Lever and Milbourne, 2014: 263).

${ }^{9}$ The cohort used for this article formed part of a larger empirical study on the 2012 London Olympic Games.

${ }^{10}$ In the interview, Hattenston (2012) adds that Farah's 'father Muktar was born in Hounslow and went to work as an IT consultant in Mogadishu, where he met his wife Amran. They lived in a big stone house, had six children and, when civil war tore Somalia apart, Amran and the children moved to neighbouring Djibouti, while Muktar returned to London. When Mo was eight, he and two siblings moved with their mother to England, to be with their father. Three children, including his twin brother 
Hassan, were left with their grandmother in Somalia, because Muktar couldn't afford to bring them all. The twins didn't see each other for 12 years' (2012).

${ }^{11}$ Nowhere within the press' coverage were attempts made to certify the Britishness of the mixed-ethnicity, Jessica Ennis. Certainly, Farah's two Olympic gold medals undoubtedly resulted in greater press attention but the latent need to qualify Farah's British identity revealed wider complexities surrounding Farah's 'outsider' status.

${ }^{12}$ In relation to the media images of retired 'Team GB' athlete, Kelly Holmes, Fortier (2005) notes that Holmes followed a process of 'deracination' within the English press. 